\title{
Decreasing Investment-cash flow Sensitivity: Further UK Evidence
}

\author{
December 13, 2019
}

\begin{abstract}
Using publicly listed firms in the UK, we examine the time-series variation of investment-cash flow sensitivity after directly controlling for future growth opportunities in cash flow, which if overlooked, as in the literature, could bias inferences. We find that investment-cash flow sensitivity is disappearing over time, even for constrained firms during the global financial crisis when credit constraints were more significant or binding. Our results not only confirm the decline in investmentcash flow sensitivity that is not explained by factors so far identified in the literature but also its diminishing usefulness as a proxy of financial constraints.
\end{abstract}

Keywords: Financial constraints, investment-cash flow sensitivity, time variations. JEL classification: G01; G31; G32

\section{Introduction}

An emerging tranche of the literature reports significant decreases in investment-cash flow sensitivity (ICFS, thereon) which casts doubt on whether it is still a good proxy of financial constraints. For example, Brown and Petersen (2009) and Chen and Chen (2012) report disappearing investment-cash flow sensitivity in the US, even during the global financial crisis when financial constraints were supposedly binding. Similarly, Moshirian et al. (2017) find significant worldwide decreases in investment-cash flow sensitivity, which they attribute to the decline in capital intensity and rising R\&D. However, Lewellen and Lewellen (2016) report a considerably higher investment-cash flow sensitivity of 0.36 and argue that low sensitivities in prior studies $(0 \%-15 \%)$ are due to methodological issues and the use of noisy measures of cash flow. Notwithstanding the above contributions, the 
mixed results even within the US where studies are concentrated suggest that the debate on investment-cash flow sensitivity is far from being fully settled.

We build upon and contribute this literature by providing further empirical evidence and highlight potential ways of resolving the mixed findings. Using a sample of 657 firms (8,562 firm-year observations) in the UK over the period 1992-2016, we re-examine the time-variations or evolution of investment-cash flow sensitivity. Our findings show that investment-cash flow sensitivity is decreasing throughout the sample period, with no marked changes during the global financial crisis when financial constraints were more significant or binding. This is consistent with Chen and Chen (2012) who argues that investment-cash flow sensitivity is not a good proxy of financial constraints for firms in the US as it does not increase when credit conditions deteriorate, but instead, decreases progressively over the period 1967-2009.

We further decompose cash flow into a permanent and transitory component using the Beveridge-Nelson (BN, thereafter) decomposition from the asset pricing literature (see Cochrane, 1994; Morley et al., 2003; Grleanu et al., 2012; Chang et al., 2014). The BN decomposition enables us to reaffirm the observed decrease in investment-cash flow sensitivity after directly controlling for future growth opportunities in cash flow which could bias inferences. ${ }^{1}$ Our results show that investment-cash flow sensitivity is decreasing significantly for both the transitory and permanent components of cash flow. This result confirms the findings of Brown and Petersen (2009), Chen and Chen (2012) and Moshirian et al. (2017), and show that investment-cash flow sensitivity is decreasing even after controlling for future growth opportunities in cash flow which have not been directly addressed in the literature.

Building on our results, we next investigate the potential reason(s) for the downward trend in investment-cash flow sensitivity. Contrary to Moshirian et al. (2017), we find that the decline in capital intensity and income predictability does not explain the evolution of

\footnotetext{
${ }^{1}$ According to Hovakimian (2009), cash flow and capital expenditure trend in opposite directions, with cash flow decreasing during periods of high growth opportunities. Similarly, Chang et al. (2014) highlights that changes in cash flow partly reflect the future growth opportunities of the firm which could lead to biased estimates of investment-cash flow sensitivity.
} 
investment-cash flow sensitivity in the UK as it decreases for both high and low-tangibility firms. Similarly, our results are inconsistent with the decline in investment-cash flow sensitivity due to rising R\&D (Brown et al., 2009), reduced agency costs (Pawlina and Renneboog, 2005) and the surge in cash holdings (Andrn and Jankensgrd, 2015). Our results which also show a pronounced decrease for both constrained and unconstrained firms even during the global financial crisis suggest that investment-cash flow sensitivity is increasingly becoming an imperfect proxy of financial constraints.

The rest of the paper is organised as follows. Section 2 presents the methodology, Section 3 presents the data used in the analyses, Section 4 discusses the empirical results, and Section 5 concludes.

\section{Methodology}

To investigate the evolution of investment-cash flow sensitivity, we estimate the following baseline model:-

$$
I_{i j t}=\alpha+\beta C F_{i j t}+\gamma Q_{i j t-1}+\epsilon_{i j t}
$$

where $I_{i j t}$ is the investment for firm $i$ at time $t, \alpha$ is a constant, $\beta$ and $\gamma$ are the coefficients to be estimated, $Q_{i j t-1}$ is Tobin's $q$, and $C F_{i j t}$ is the firm's cash flow. Finally, $\epsilon_{i j t}$ is the firm-year specific error term.

We augment our baseline model to incorporate the transitory (cycle) and permanent (trend) components of cash flow as follows:

$$
\begin{aligned}
I_{i j t}= & \alpha+\beta^{\text {Cycle }} C F_{i j t}^{\text {Cycle }}+\beta^{\text {Trend }} C F_{i j t}^{\text {Trend }} \\
& +\gamma Q_{i j t-1}+\epsilon_{i j t}
\end{aligned}
$$

where $C F_{i j t}^{C y c l e}$ is the firm's cycle of cash flow, and $C F_{i j t}^{\text {Trend }}$ is the firm's trend of cash flow. Cash flow is decomposed into a cycle and trend component using Beveridge-Nelson 
decomposition. The change in unscaled cash flow (earnings before extraordinary items plus depreciation), $\Delta y_{t}$, is empirically fitted using an $A R I M A(p, q)$ to obtain the cycle component of cash flow and then, the trend component is calculated as the difference between the cash flow and cycle component of cash flow. ${ }^{2}$ The transitory component of cash flow, $C F_{i j t}^{C y c l e}$, is volatile and carry less information about future growth opportunities which could explain the decline in investment-cash flow sensitivity.

Following on Chen and Chen (2012), we estimate Equations (1) and (2) using fixed effects (FE) and ordinary least squares (OLS). All estimations include year fixed effects (not reported for brevity). We report standard errors that are robust to heteroskedasticity and clustered at firm-level. ${ }^{3}$ To examine the time variation in investment-cash flow sensitivity, we create five sub-periods of five-year intervals: p1 (1992-1996), p2 (1997-2001), p3 (2002-2006), p4 (2007-2011) and p5 (2012-2016). ${ }^{4}$

\section{Data}

Our data is extracted from Datastream over the period 1992-2016 and excludes firms in the financial and utility sectors, and those with missing observations. To reduce the effects of outliers, we winsorise all variables at the upper and bottom 1\%. Our final sample consists of 8,562 firm-year observations for 657 firms. Table 1 describes in detail each of the variables used.

\section{PLEASE INSERT TABLE 1 HERE}

\section{PLEASE INSERT TABLE 2 HERE}

\footnotetext{
${ }^{2}$ See Chang et al. (2014) and Morley et al. (2003) for a detailed discussion of the Beveridge-Nelson decomposition and its application to panel data and time series, respectively.

${ }^{3}$ For robustness, we re-estimate our empirical models using the general method of moments (GMM) based on higher-order moments to correct for potential mismeasurement errors associated with Tobin's $q$ (see Erickson and Whited, 2000, 2002; Bao et al., 2012). These results which are qualitatively similar are available upon request.

${ }^{4}$ To reduce concerns that our subjective selection of sub-periods could introduce unintended biases, in unreported results, we also re-estimate the main models using 5-year rolling regressions (21 overlapping sub-periods).
} 
Table 2 presents 5-year rolling summary statistics for all variables used. During the sample period, investment and cash flow decreased by $38 \%$ and $17 \%$, respectively. This result raises concern that the reported decrease in investment-cash flow sensitivity could be attributable to the concurrent decline in both investment and cash flow rather than arising from investment-cash flow sensitivity being a poor proxy of financial constraints. We directly address this concern by decomposing cash flow into transitory (cycle) and permanent (trend) components using the Beveridge-Nelson decomposition. Table 2 shows that the transitory and permanent components of cash flow evolve in opposite directions.

Table 3 presents the pairwise correlations for variables. Investment correlates positively with cash flow, the transitory (cycle) and permanent (trend) components of cash flow, and Tobin's $q .{ }^{5}$ All correlations are of the expected sign, except for the negative correlation between transitory and trend component of cash flow which indicates that decomposing cash flow could help provide better tests of whether investment-cash flow sensitivity is a good proxy of financial constraints. ${ }^{6}$

\section{PLEASE INSERT TABLE 3 HERE}

\section{Empirical Results}

We first examine whether investment-cash flow sensitivity is decreasing over the sample period and then proceed to investigate the reasons for the trend.

\subsection{Is investment-cash flow decreasing?}

Table 4 presents the results estimating Equation (1) that relates investment to cash flow and Tobin's q over five sub-periods (p1 (1992-1996), p2 (1997-2001), p3 (2002-2006), p4

\footnotetext{
${ }^{5}$ The positive and significant correlation of the transitory (cycle) component of cash flow and investment show, a priori, that cash flow still influences investment decisions despite its decline and instability (Moshirian et al., 2017; Lewellen and Lewellen, 2016).

${ }^{6}$ Our untabulated results show that the correlation between investment and cash flow is decreasing over time (even for the restricted sample of firms with positive cash flow). We also find that the correlations between investment and transitory (cycle) component of cash flow, and investment and the permanent (trend) component of cash flow evolve in opposite directions throughout the sample period.
} 
(2007-2011) and p5 (2012-2016)).

\section{PLEASE INSERT TABLE 4 HERE}

Table 4 shows a significant investment-cash flow sensitivity of 0.093 over the sample period. This result is in line with US studies of Brown and Petersen (2009) and Chen and Chen (2012) and suggests that firms in the UK increase investment by 0.159 for a one standard deviation increase in cash flow. Our time-series estimates show that investmentcash flow sensitivity has decreased by $79 \%$ from a peak of 0.173 for the period $1992-1996$ (p1) to 0.037 for the period $2012-2016$ (p5). ${ }^{7}$ These results are surprising given that the post-global financing crisis period was characterised by significant adverse credit supply shocks which, in theory, should lead to an increase in investment-cash flow sensitivity.

We next examine whether investment-cash flow sensitivity is decreasing for both the transitory (cycle) and permanent (trend) components of cash flow. Panel B of Table 4 presents the results estimating Equation (2) which relates investment to the transitory (cycle) and permanent (trend) components of cash flow, and Tobin's q. The positive and significant coefficients of $C F^{\text {Cycle }}(0.063)$ and $C F^{\text {Trend }}(0.090)$ are consistent with our main findings. However, this is contrary to Lewellen and Lewellen (2016) and Moshirian et al. (2017) who attribute the decrease in investment-cash flow sensitivity to the increase in cash flow volatility. Instead, our results after directly controlling for future growth opportunities by decomposing cash into transitory (cycle) and permanent (trend) components show that operating cash flow still has a significant impact on investments despite its instability.

Our further sub-sample analyses show a $62 \%$ and $88 \%$ decrease in the coefficients of $C F^{\text {Cycle }}$ and $C F^{\text {Trend }}$ for the period 2012-2016 (p5) relative to 1992-1996 (p1), respectively. Theoretically, the cycle component of cash flow, $C F^{C y c l e}$, should have an insignificant or weak effect on investment as it is less reliable and does not provide any information about the firm's future growth opportunities. However, our results suggest

\footnotetext{
${ }^{7}$ Our results are robust to controlling for additional factors such as cash holdings, firm-size and leverage (debt) that could affect the investment decisions.
} 
otherwise, because the cycle component of cash flow is as important as the permanent component $\left(C F^{\text {Trend }}\right)$. This implies that the decrease in investment-cash flow sensitivity for UK firms is not explained by the increase in cash flow volatility as reported by Lewellen and Lewellen (2016) and Moshirian et al. (2017). By directly controlling for future growth opportunities in cash flow which could potentially bias inferences, we provide stricter tests and corroborative empirical evidence from a different context on the evolution of investment-cash flow sensitivity. ${ }^{8}$

\subsection{Why is investment-cash flow sensitivity decreasing?}

So far, we have established that investment-cash flow sensitivity is declining in the UK and that this trend is not explained by changes in cash flow volatility. We next build on these results and contribute to the literature by examining potential reasons for this downward trend in investment-cash flow sensitivity. To accomplish this objective, we partition the sample based on the WW Index (Whited, 2006), KZ Index (Kaplan and Zingales, 1997), SA Index (Hadlock and Pierce, 2010), size, firm-age (Age), tangibility (PPE), debt, dividends (DivD), cash holdings (Cash), R\&D (RDD) and industry (IND).

Table 5 summaries the estimation results of Equation (1) for the sub-samples.

\section{PLEASE INSERT TABLE 5 HERE}

Table 5 shows a consistent decrease in investment-cash flow sensitivity for all subsamples based on several measures of financial constraints and across manufacturing and non-manufacturing sectors. Specifically, for sub-samples based on WW Index, KZ Index, SA Index, size, firm-age, tangibility, debt and dividends, we find similar decreases in investment-cash flow sensitivity for both constrained and unconstrained firms. Our results suggest that despite the heterogeneity in firm-specific factors, firms in the UK

\footnotetext{
${ }^{8}$ To ensure that our results are robust to mismeasurement errors associated with Tobin's $q$, in Appendix A, we present estimates of investment-cash flow sensitivity based on GMM5 of Erickson and Whited (2000, 2002). The GMM uses higher-order moments to correct for mismeasurement errors associated with Tobin's $q$ that could potentially bias estimates of investment-cash flow sensitivity. Consistent with our main results, Appendix A shows that investment-cash flow sensitivity is similarly decreasing over time.
} 
experience similar decreases in investment-cash flow sensitivity. This similar evolution of investment-cash flow sensitivity across the sub-groups of firms is not consistent with either the reduced agency costs hypothesis as put forward by Pawlina and Renneboog (2005) or the financial constraint hypothesis (Chen and Chen, 2012). Thus, differences in agency problems between larger and high-tangibility firms relative to smaller and low-tangibility firms do not explain the decrease in investment-cash flow sensitivity.

We next investigate the effects of cash holdings on investment-cash flow sensitivity (Andrn and Jankensgrd, 2015). The results in Table 5 show a consistent decrease in investment-cash flow sensitivity, with the decrease being less pronounced for firms with low cash holdings relative to those with high cash holdings. This is inconsistent with Andrn and Jankensgrd (2015) (for the case of US firms) and suggests that rising cash holdings do not explain the decline in investment-cash flow sensitivity within the UK context. We find similar decreases for sub-samples based on corporate debt, which suggest that changes in the capital structure are unlikely to explain the downward trend in investment-cash flow sensitivity.

Our comparisons of the differences in investment-cash flow sensitivity between $R \& D$ $(R \& D>0)$ and Non-R\&D $(R \& D=0)$ firms in Table 5 show remarkably similar decreases across the sub-samples even though the decline is more pronounced for the former relative to the latter sub-group. This is inconsistent with Borisova and Brown (2013) who find that the decrease in investment-cash flow sensitivity for US firms is due to the rise in R\&D.

Table 5 also shows that investment-cash flow sensitivity is decreasing for both manufacturing (Man) and non-manufacturing (Non-Man) firms. This similar evolution suggests that decline in investment-cash flow sensitivity is not confined to one particular industry.

Taken together, our results confirm that investment-cash flow sensitivity is not a good proxy of financial constraints for firms operating in the UK as it is decreasing over time and even during the global financial crisis for firms that are more likely to face binding financial constraints. 


\section{Conclusion}

We examine the time-series variations in investment-cash flow sensitivity using non-utility and non-financial publicly listed firms in the UK over the past twenty-five years. Our results confirm that investment-cash flow sensitivity is decreasing over time and even during the period of the global financial crisis it was expected to increase. We also find that the decrease in investment-cash flow sensitivity is not explained by factors identified in the literature. Our empirical tests further cast doubt the usefulness of investmentcash flow sensitivity as a proxy of financial constraints beyond the US where studies are concentrated.

\section{$6 \quad$ Funding}

This research did not receive any specific grant from funding agencies in the public, commercial, or not-for-profit sectors.

\section{References}

Andrn, N. and Jankensgrd, H. (2015). Wall of cash: The investment-cash flow sensitivity when capital becomes abundant. Journal of Banking $\& 3$ Finance, 50:204-213.

Bao, D., Chan, K. C., and Zhang, W. (2012). Asymmetric cash flow sensitivity of cash holdings. Journal of Corporate Finance, 18(4):690-700.

Borisova, G. and Brown, J. R. (2013). R\&D Sensitivity to Asset Sale Proceeds: New Evidence on Financing Constraints and Intangible Investment. Journal of Banking $\mathscr{E}$ Finance, 37(1):159-173.

Brown, J. R., Fazzari, S. M., and Petersen, B. C. (2009). Financing Innovation and Growth: Cash Flow, External Equity, and the 1990s R\&D Boom. The Journal of Finance, 64(1):151-185. 
Brown, J. R. and Petersen, B. C. (2009). Why has the Investment-Cash Flow Sensitivity Declined so Sharply? Rising R\&D and Equity Market Developments. Journal of Banking \& Finance, 33(5):971-984.

Chang, X., Dasgupta, S., Wong, G., and Yao, J. (2014). Cash-Flow Sensitivities and the Allocation of Internal Cash Flow. The Review of Financial Studies, 27(12):3628-3657.

Chen, H. J. and Chen, S. J. (2012). Investment-Cash Flow Sensitivity Cannot be a Good Measure of Financial Constraints: Evidence from the Time Series. Journal of Financial Economics, 103(2):393-410.

Cochrane, J. H. (1994). Permanent and Transitory Components of GNP and Stock Prices. The Quarterly Journal of Economics, 109(1):241-265.

Erickson, T. and Whited, T. M. (2000). Measurement Error and the Relationship between Investment and q. Journal of Political Economy, 108(5):1027-1057.

Erickson, T. and Whited, T. M. (2002). Two-Step GMM Estimation of the Errors-inVariables Model Using High-Order Moments. Econometric Theory, 18(3):776-799.

Grleanu, N., Kogan, L., and Panageas, S. (2012). Displacement risk and asset returns. Journal of Financial Economics, 105(3):491-510.

Hadlock, C. J. and Pierce, J. R. (2010). New Evidence on Measuring Financial Constraints: Moving Beyond the KZ Index. The Review of Financial Studies, 23(5):19091940.

Hovakimian, G. (2009). Determinants of Investment Cash Flow Sensitivity. Financial Management, 38(1):161-183.

Kaplan, S. N. and Zingales, L. (1997). Do Investment-Cash Flow Sensitivities Provide Useful Measures of Financing Constraints? The Quarterly Journal of Economics, $112(1): 169-215$. 
Lewellen, J. and Lewellen, K. (2016). Investment and Cash Flow: New Evidence. Journal of Financial and Quantitative Analysis, 51(4):1135-1164.

Morley, J. C., Nelson, C. R., and Zivot, E. (2003). Why Are the Beveridge-Nelson and Unobserved-Components Decompositions of GDP so Different? The Review of Economics and Statistics, 85(2):235-243.

Moshirian, F., Nanda, V., Vadilyev, A., and Zhang, B. (2017). What drives investmentcash flow sensitivity around the World? An asset tangibility Perspective. Journal of Banking \& Finance, 77:1-17.

Pawlina, G. and Renneboog, L. (2005). Is Investment-Cash Flow Sensitivity Caused by Agency Costs or Asymmetric Information? Evidence from the UK. European Financial Management, 11(4):483-513.

Whited, T. M. (2006). External Finance Constraints and the Intertemporal Pattern of Intermittent Investment. Journal of Financial Economics, 81(3):467-502. 
Table 1 Variable definitions

\begin{tabular}{|c|c|}
\hline Variable & Definition \\
\hline$I$ & Physical capital expenditure to lagged total assets. \\
\hline$C F$ & Earnings before extraordinary items plus depreciation (operating cash flow) to lagged total assets. \\
\hline$C F^{C y c l e}$ & $\begin{array}{l}\text { The cycle in cash flow to lagged total assets. The cycle is calculated based on the Beveridge-Nelson } \\
\text { decomposition (see Chang et al., 2014). }\end{array}$ \\
\hline$C F^{\text {Trend }}$ & $\begin{array}{l}\text { The trend in cash flow to lagged total assets. The trend is the difference between the cash flow and } \\
\text { the cycle in the cash flow (see Chang et al., 2014). }\end{array}$ \\
\hline$Q$ & Total assets-book value of equity +market value of equity divided by total assets (Tobin's $q$ ). \\
\hline$W W$ Index & $\begin{array}{l}\text { The WW Index is based on (Whited, 2006) and is calculated as follows: } \\
-0.091 \times C F-0.062 \times \text { DivD }+0.021 \times \text { Debt }-0.044 \times \text { Size }+0.102 \times I S G-0.035 \times S G \text {. }\end{array}$ \\
\hline$S G$ & Sales growth. \\
\hline$I S G$ & Industrial sales growth. \\
\hline$K Z$ Index & $\begin{array}{l}\text { The KZ Index is based on Kaplan and Zingales }(1997) \text { and is calculated as follows: } \\
-1.002 \times C F+0.283 \times \text { Debt }-39.368 \times \text { Dividends }-1.315 \times \text { Cash }\end{array}$ \\
\hline$S A$ Index & $\begin{array}{l}\text { The SA Index is based on Hadlock and Pierce (2010) and is calculated as follows: } \\
-0.737 \times \text { Size }+0.043 \times \text { Size }^{2}-0.040 \times \text { Age }\end{array}$ \\
\hline Dividends & Dividend paid to total assets. \\
\hline Size & The logarithm of total assets. \\
\hline Age & Age is calculated as the current year less the first year a firm is reported in Datastream. \\
\hline$P P E$ & Property, plant and equipment to total assets (tangibility). \\
\hline Leverage & Total debt to total assets (Debt). \\
\hline DivD & A dummy variable that takes the value of one if a firm pays a dividend and otherwise zero. \\
\hline Cash & Cash holdings to lagged total assets. \\
\hline$R D D$ & A dummy variable that takes the value of one if a firm reports $R \& D$ and otherwise zero. \\
\hline$R \mathscr{E} D$ & Research and development to total assets. \\
\hline IND & $\begin{array}{l}\text { A dummy variable that takes the of one if a firm is classified as being in the industrials sector (IND) } \\
\text { based on Industry Classification Benchmark (ICB) and otherwise zero. }\end{array}$ \\
\hline
\end{tabular}

Note: The table lists the definitions of all variables used and the account items obtained from Datastream databases. 
Table 2 Basic statistics

\begin{tabular}{|c|c|c|c|c|c|c|c|c|}
\hline \multirow[b]{2}{*}{ Variables } & \multirow[b]{2}{*}{ Period } & \multirow{2}{*}{$\begin{array}{l}\mathrm{p} 1 \\
1992-1996\end{array}$} & \multirow{2}{*}{$\begin{array}{l}\text { p2 } \\
1997-2001\end{array}$} & \multirow{2}{*}{$\begin{array}{l}\text { p3 } \\
2002-2006\end{array}$} & \multirow{2}{*}{$\begin{array}{l}\mathrm{p} 4 \\
2007-2011\end{array}$} & \multirow{2}{*}{$\begin{array}{l}\text { p5 } \\
2012-2016\end{array}$} & \multirow{2}{*}{$\begin{array}{l}\text { All } \\
1996-2016\end{array}$} & \multirow{2}{*}{$\begin{array}{l}\text { Diff } \\
(\mathrm{p} 1=\mathrm{p} 5)\end{array}$} \\
\hline & & & & & & & & \\
\hline \multirow{3}{*}{$I$} & Mean & 0.068 & 0.076 & 0.053 & 0.048 & 0.042 & 0.053 & $-0.026^{* * *}$ \\
\hline & Median & 0.057 & 0.057 & 0.037 & 0.026 & 0.025 & 0.035 & $-0.032^{* * *}$ \\
\hline & Stdev & 0.055 & 0.067 & 0.054 & 0.060 & 0.049 & 0.058 & $-0.006^{* * *}$ \\
\hline \multirow{3}{*}{$C F$} & Mean & 0.110 & 0.115 & 0.093 & 0.094 & 0.091 & 0.098 & $-0.019^{* * *}$ \\
\hline & Median & 0.110 & 0.117 & 0.100 & 0.093 & 0.092 & 0.099 & $-0.018^{* * *}$ \\
\hline & Stdev & 0.082 & 0.100 & 0.104 & 0.103 & 0.100 & 0.100 & $0.018^{* * *}$ \\
\hline \multirow{3}{*}{$C F^{C y c l e}$} & Mean & 0.000 & 0.004 & 0.001 & 0.005 & -0.003 & 0.001 & -0.003 \\
\hline & Median & 0.001 & 0.002 & -0.001 & 0.002 & -0.001 & 0.000 & $-0.002^{* *}$ \\
\hline & Stdev & 0.050 & 0.055 & 0.050 & 0.055 & 0.053 & 0.053 & $0.003^{* *}$ \\
\hline \multirow{3}{*}{$C F^{\text {Trend }}$} & Mean & 0.108 & 0.110 & 0.091 & 0.088 & 0.095 & 0.096 & $-0.013^{* * *}$ \\
\hline & Median & 0.103 & 0.106 & 0.096 & 0.086 & 0.092 & 0.095 & $-0.011^{* * *}$ \\
\hline & Stdev & 0.096 & 0.106 & 0.107 & 0.105 & 0.104 & 0.105 & $0.008^{* * *}$ \\
\hline \multirow{4}{*}{$Q$} & Mean & 1.569 & 1.783 & 1.618 & 1.544 & 1.643 & 1.623 & $0.074^{* *}$ \\
\hline & Median & 1.407 & 1.427 & 1.329 & 1.290 & 1.349 & 1.346 & $-0.058^{* *}$ \\
\hline & Stdev & 0.770 & 1.146 & 0.942 & 0.895 & 0.990 & 0.961 & $0.220^{* * *}$ \\
\hline & $\mathrm{N}$ & 915 & 1236 & 1699 & 2368 & 2344 & 8562 & \\
\hline
\end{tabular}

Note: The table presents the summary statistics for all the variables used. $I$ is corporate investment, $C F$ is the firm's cash flow, $C F^{C y c l e}$ is the firm's cycle of cash flow, $C F^{T r e n d}$ is the firm's trend of cash flow and $Q$ is Tobin's $q$. The sample consists of listed non-utility and non-financial firms in the UK drawn from Datastream over the period 1992-2016. All variables used are defined in Table 1 and are winsorised at the lower and upper one percentiles.

\section{Table 3 Correlations}

\begin{tabular}{llllll}
\hline Variables & $I$ & $C F$ & $C F^{C y c l e}$ & $C F^{\text {Trend }}$ & $Q$ \\
\hline$I$ & 1 & $0.381^{* * *}$ & $0.019^{*}$ & $0.349^{* * *}$ & $0.248^{* * *}$ \\
$C F$ & $0.329^{* * *}$ & 1 & $0.160^{* * *}$ & $0.878^{* * *}$ & $0.543^{* * *}$ \\
$C F^{\text {Cycle }}$ & $0.028^{* *}$ & $0.205^{* * *}$ & 1 & $-0.209^{* * *}$ & $0.046^{* * *}$ \\
$C F^{\text {Trend }}$ & $0.297^{* * *}$ & $0.861^{* * *}$ & $-0.298^{* * *}$ & 1 & $0.494^{* * *}$ \\
$Q$ & $0.191^{* * *}$ & $0.411^{* * *}$ & $0.044^{* * *}$ & $0.372^{* * *}$ & 1 \\
\hline
\end{tabular}

Note: The table presents the Pearson and Spearman pairwise correlations for all variables used in the lower and upper diagonal, respectively. The sample consists of listed non-utility and non-financial firms in the UK drawn from Datastream over the period 1992-2016. All variables used are defined in Table 1 and are winsorised at the lower and upper one percentiles. ${ }^{* *},{ }^{*}, *$ indicate significance at the one, five, and ten percent levels, respectively. 


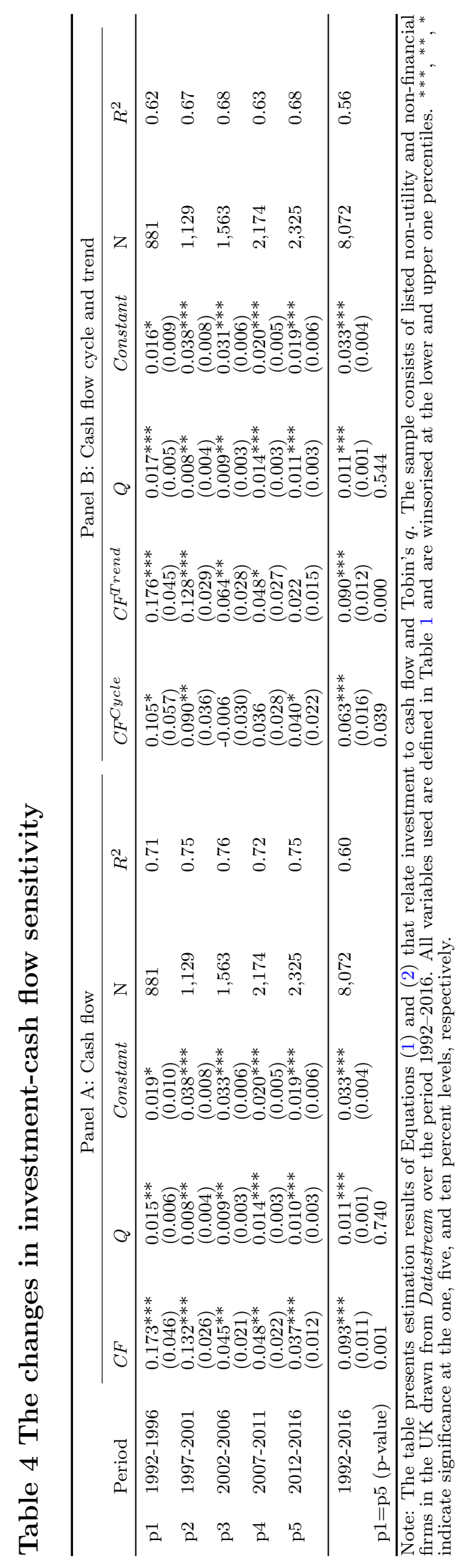


Table 5 Asymmetric changes in investment-cash flow sensitivity

\begin{tabular}{|c|c|c|c|c|c|c|c|c|c|}
\hline \multirow[b]{2}{*}{ Variables } & \multirow[b]{2}{*}{ Period } & \multirow{2}{*}{$\begin{array}{l}\mathrm{p} 1 \\
1992- \\
1996 \\
\end{array}$} & \multirow{2}{*}{$\begin{array}{l}\mathrm{p} 2 \\
1997- \\
2001\end{array}$} & \multirow{2}{*}{$\begin{array}{l}\text { p3 } \\
2002- \\
2006\end{array}$} & \multirow{2}{*}{$\begin{array}{l}\mathrm{p} 4 \\
2007- \\
2011 \\
\end{array}$} & \multirow{2}{*}{$\begin{array}{l}\text { p5 } \\
2012- \\
2016 \\
\end{array}$} & \multirow{2}{*}{$\begin{array}{l}\text { All } \\
1992- \\
2016 \\
\end{array}$} & \multicolumn{2}{|c|}{ Differences } \\
\hline & & & & & & & & $(\mathrm{p} 1=\mathrm{p} 5)$ & $\% \Delta$ \\
\hline \multirow[t]{2}{*}{ WW } & Low & $\begin{array}{l}0.204^{*} \\
(0.114)\end{array}$ & $\begin{array}{l}0.157^{* * *} \\
(0.046)\end{array}$ & $\begin{array}{l}0.108^{* * *} \\
(0.041)\end{array}$ & $\begin{array}{l}0.069 * * \\
(0.035)\end{array}$ & $\begin{array}{l}0.029 \\
(0.020)\end{array}$ & $\begin{array}{l}0.116^{* * * *} \\
(0.023)\end{array}$ & $\begin{array}{l}-0.144 \\
(0.132)\end{array}$ & $-86 \%$ \\
\hline & High & $\begin{array}{l}0.154 * * * \\
(0.047)\end{array}$ & $\begin{array}{l}0.125 * * * \\
(0.035)\end{array}$ & $\begin{array}{l}0.034^{*} \\
(0.018)\end{array}$ & $\begin{array}{l}0.035 \\
(0.029)\end{array}$ & $\begin{array}{l}0.043^{* * *} \\
(0.016)\end{array}$ & $\begin{array}{l}0.082^{* * * *} \\
(0.013)\end{array}$ & $\begin{array}{l}-0.246 * * * \\
(0.062)\end{array}$ & $-72 \%$ \\
\hline \multirow[t]{2}{*}{$\mathrm{KZ}$} & Low & $\begin{array}{l}0.237^{* * *} \\
(0.084)\end{array}$ & $\begin{array}{l}0.120 * * * \\
(0.035)\end{array}$ & $\begin{array}{l}0.057 \\
(0.040)\end{array}$ & $\begin{array}{l}0.084 * * \\
(0.042)\end{array}$ & $\begin{array}{l}0.052 * * \\
(0.021)\end{array}$ & $\begin{array}{l}0.100 * * * \\
(0.018)\end{array}$ & $\begin{array}{l}-0.208^{* *} \\
(0.093)\end{array}$ & $-78 \%$ \\
\hline & High & $\begin{array}{l}0.139 * * * \\
(0.052)\end{array}$ & $\begin{array}{l}0.107^{* * *} \\
(0.041)\end{array}$ & $\begin{array}{l}0.034 \\
(0.031)\end{array}$ & $\begin{array}{l}0.047 \\
(0.032)\end{array}$ & $\begin{array}{l}0.033^{*} \\
(0.019)\end{array}$ & $\begin{array}{l}0.082^{* * * *} \\
(0.013)\end{array}$ & $\begin{array}{c}-0.175^{*} \\
(0.091)\end{array}$ & $-76 \%$ \\
\hline \multirow[t]{2}{*}{$\mathrm{SA}$} & Low & $\begin{array}{l}0.134^{* * * *} \\
(0.040)\end{array}$ & $\begin{array}{l}0.114^{* * *} \\
(0.030)\end{array}$ & $\begin{array}{l}0.027 \\
(0.018)\end{array}$ & $\begin{array}{l}0.042 \\
(0.031)\end{array}$ & $\begin{array}{l}0.050^{* * *} \\
(0.014)\end{array}$ & $\begin{array}{l}0.077^{* * * *} \\
(0.012)\end{array}$ & $\begin{array}{l}-0.157^{* *} \\
(0.063)\end{array}$ & $-63 \%$ \\
\hline & High & $\begin{array}{l}0.248^{* *} \\
(0.111)\end{array}$ & $\begin{array}{l}0.187^{* * *} \\
(0.054)\end{array}$ & $\begin{array}{l}0.093 \\
(0.071)\end{array}$ & $\begin{array}{l}0.057^{*} \\
(0.032)\end{array}$ & $\begin{array}{l}0.024 \\
(0.023)\end{array}$ & $\begin{array}{l}0.113^{* * * *} \\
(0.020)\end{array}$ & $\begin{array}{l}-0.320 * * * \\
(0.123)\end{array}$ & $-90 \%$ \\
\hline \multirow[t]{2}{*}{ Size } & Low & $\begin{array}{l}0.141^{* * * *} \\
(0.040)\end{array}$ & $\begin{array}{l}0.125^{* * *} \\
(0.034)\end{array}$ & $\begin{array}{l}0.033^{*} \\
(0.018)\end{array}$ & $\begin{array}{l}0.032 \\
(0.028)\end{array}$ & $\begin{array}{l}0.044^{* * * *} \\
(0.015)\end{array}$ & $\begin{array}{l}0.077^{* * * *} \\
(0.012)\end{array}$ & $\begin{array}{l}-0.213^{* * *} \\
(0.060)\end{array}$ & $-69 \%$ \\
\hline & High & $\begin{array}{l}0.201 * * \\
(0.084)\end{array}$ & $\begin{array}{l}0.138^{* * *} \\
(0.040)\end{array}$ & $\begin{array}{l}0.098^{*} \\
(0.054)\end{array}$ & $\begin{array}{l}0.084^{* *} \\
(0.035)\end{array}$ & $\begin{array}{l}0.011 \\
(0.020)\end{array}$ & $\begin{array}{l}0.118^{* * *} \\
(0.023)\end{array}$ & $\begin{array}{l}-0.213^{* * *} \\
(0.075)\end{array}$ & $-95 \%$ \\
\hline \multirow[t]{2}{*}{ Age } & Low & $\begin{array}{l}0.130 * * * \\
(0.040)\end{array}$ & $\begin{array}{l}0.126^{* * *} \\
(0.030)\end{array}$ & $\begin{array}{l}0.048^{*} \\
(0.027)\end{array}$ & $\begin{array}{l}0.022 \\
(0.027)\end{array}$ & $\begin{array}{l}0.027^{*} \\
(0.016)\end{array}$ & $\begin{array}{l}0.082^{* * * *} \\
(0.014)\end{array}$ & $\begin{array}{l}-0.162 * * * \\
(0.059)\end{array}$ & $-79 \%$ \\
\hline & High & $\begin{array}{l}0.316^{* *} \\
(0.137) \\
\end{array}$ & $\begin{array}{l}0.142^{* *} \\
(0.056)\end{array}$ & $\begin{array}{l}0.037 \\
(0.028)\end{array}$ & $\begin{array}{l}0.110^{* * *} \\
(0.039)\end{array}$ & $\begin{array}{l}0.055^{* * *} * \\
(0.016)\end{array}$ & $\begin{array}{l}0.117^{* * * *} \\
(0.020)\end{array}$ & $\begin{array}{l}-0.343^{* * *} \\
(0.124)\end{array}$ & $-83 \%$ \\
\hline \multirow[t]{2}{*}{ PPE } & Low & $\begin{array}{l}0.202^{* *} \\
(0.078)\end{array}$ & $\begin{array}{l}0.097^{* * * *} \\
(0.027)\end{array}$ & $\begin{array}{l}0.022 \\
(0.017)\end{array}$ & $\begin{array}{l}0.015 \\
(0.017)\end{array}$ & $\begin{array}{l}0.021^{* *} \\
(0.010)\end{array}$ & $\begin{array}{l}0.050^{* * * *} \\
(0.010)\end{array}$ & $\begin{array}{l}-0.218 * * * \\
(0.057)\end{array}$ & $-90 \%$ \\
\hline & High & $\begin{array}{l}0.140^{* * *} \\
(0.049) \\
\end{array}$ & $\begin{array}{l}0.167^{* * *} * \\
(0.047) \\
\end{array}$ & $\begin{array}{l}0.067 \\
(0.046)\end{array}$ & $\begin{array}{l}0.117^{* * * *} \\
(0.045) \\
\end{array}$ & $\begin{array}{l}0.040 * \\
(0.023)\end{array}$ & $\begin{array}{l}0.123^{* * * *} \\
(0.017) \\
\end{array}$ & $\begin{array}{l}-0.081 \\
(0.067)\end{array}$ & $-71 \%$ \\
\hline \multirow[t]{2}{*}{ Debt } & Low & $\begin{array}{l}0.139^{* * *} \\
(0.065)\end{array}$ & $\begin{array}{l}0.123 * * \\
(0.053)\end{array}$ & $\begin{array}{l}0.031 \\
(0.034)\end{array}$ & $\begin{array}{l}0.033 \\
(0.034)\end{array}$ & $\begin{array}{l}0.050 * * \\
(0.024)\end{array}$ & $\begin{array}{l}0.080^{* * * *} \\
(0.015)\end{array}$ & $\begin{array}{l}-0.218^{* * *} \\
(0.076)\end{array}$ & $-64 \%$ \\
\hline & High & $\begin{array}{l}0.176 * * \\
(0.071)\end{array}$ & $\begin{array}{l}0.123^{* * *} \\
(0.029)\end{array}$ & $\begin{array}{l}0.054 * * \\
(0.027)\end{array}$ & $\begin{array}{l}0.070 \\
(0.042)\end{array}$ & $\begin{array}{l}0.024 \\
(0.017)\end{array}$ & $\begin{array}{l}0.102^{* * *} \\
(0.018)\end{array}$ & $\begin{array}{l}-0.199 * * * \\
(0.075)\end{array}$ & $-86 \%$ \\
\hline \multirow[t]{2}{*}{ Div } & $\operatorname{DivD}=0$ & $\begin{array}{l}0.125 \\
(0.159) \\
\end{array}$ & $\begin{array}{l}-0.043 \\
(0.119)\end{array}$ & $\begin{array}{l}0.001 \\
(0.039)\end{array}$ & $\begin{array}{l}0.008 \\
(0.036)\end{array}$ & $\begin{array}{l}0.026 \\
(0.022)\end{array}$ & $\begin{array}{l}0.029 * \\
(0.015)\end{array}$ & $\begin{array}{c}-0.202^{*} \\
(0.107)\end{array}$ & $-79 \%$ \\
\hline & $\operatorname{DivD}=1$ & $\begin{array}{l}0.159^{* * *} \\
(0.059) \\
\end{array}$ & $\begin{array}{l}0.144^{* * * *} \\
(0.030) \\
\end{array}$ & $\begin{array}{l}0.066^{* * *} \\
(0.029) \\
\end{array}$ & $\begin{array}{l}0.078^{* *} * \\
(0.034) \\
\end{array}$ & $\begin{array}{l}0.046^{* * *} \\
(0.015) \\
\end{array}$ & $\begin{array}{l}0.123^{* * *} \\
(0.016) \\
\end{array}$ & $\begin{array}{l}-0.179 * * \\
(0.071) \\
\end{array}$ & $-71 \%$ \\
\hline \multirow[t]{2}{*}{ Cash } & Low & $\begin{array}{l}0.147 * * * \\
(0.045)\end{array}$ & $\begin{array}{l}0.102^{* * * *} \\
(0.038)\end{array}$ & $\begin{array}{l}0.032 \\
(0.031) \\
\end{array}$ & $\begin{array}{l}0.083 * * * \\
(0.031)\end{array}$ & $\begin{array}{l}0.032^{*} \\
(0.017)\end{array}$ & $\begin{array}{l}0.098^{* * * *} \\
(0.014)\end{array}$ & $\begin{array}{c}-0.108 \\
(0.070) \\
\end{array}$ & $-78 \%$ \\
\hline & High & $\begin{array}{l}0.193^{*} \\
(0.102)\end{array}$ & $\begin{array}{l}0.127^{* * *} \\
(0.035)\end{array}$ & $\begin{array}{l}0.036 \\
(0.034)\end{array}$ & $\begin{array}{l}0.014 \\
(0.030)\end{array}$ & $\begin{array}{l}0.041 * * \\
(0.018)\end{array}$ & $\begin{array}{l}0.072^{* * * *} \\
(0.015)\end{array}$ & $\begin{array}{l}-0.215^{* * *} \\
(0.077)\end{array}$ & $-79 \%$ \\
\hline \multirow[t]{2}{*}{$\mathrm{R} \& \mathrm{D}$} & $\mathrm{RDD}=0$ & $\begin{array}{l}0.236 * * * \\
(0.070)\end{array}$ & $\begin{array}{l}0.128^{* * *} \\
(0.034)\end{array}$ & $\begin{array}{l}0.057 \\
(0.041)\end{array}$ & $\begin{array}{l}0.061^{*} \\
(0.035)\end{array}$ & $\begin{array}{l}0.053^{* * *} \\
(0.019)\end{array}$ & $\begin{array}{l}0.107^{* * * *} \\
(0.017)\end{array}$ & $\begin{array}{l}-0.190^{* *} \\
(0.081)\end{array}$ & $-78 \%$ \\
\hline & $\mathrm{RDD}=1$ & $\begin{array}{l}0.062^{* * *} \\
(0.027)\end{array}$ & $\begin{array}{l}0.138^{* * * *} \\
(0.044)\end{array}$ & $\begin{array}{l}0.033^{* * *} \\
(0.012)\end{array}$ & $\begin{array}{l}0.026 \\
(0.023)\end{array}$ & $\begin{array}{l}0.015 \\
(0.019)\end{array}$ & $\begin{array}{l}0.065^{* * *} \\
(0.014)\end{array}$ & $\begin{array}{l}-0.184^{* *} \\
(0.076)\end{array}$ & $-76 \%$ \\
\hline \multirow[t]{2}{*}{ IND } & Non-Man & $\begin{array}{l}0.142^{* *} \\
(0.060)\end{array}$ & $\begin{array}{l}0.125^{* * *} * \\
(0.034)\end{array}$ & $\begin{array}{l}0.024 \\
(0.028)\end{array}$ & $\begin{array}{l}0.046 \\
(0.028)\end{array}$ & $\begin{array}{l}0.027^{*} \\
(0.015)\end{array}$ & $\begin{array}{l}0.075^{* * *} \\
(0.014) \\
\end{array}$ & $\begin{array}{l}-0.275^{* * * *} \\
(0.079)\end{array}$ & $-81 \%$ \\
\hline & Man & $\begin{array}{l}0.208^{* * *} \\
(0.060)\end{array}$ & $\begin{array}{l}0.147^{* * * *} \\
(0.042)\end{array}$ & $\begin{array}{l}0.077^{* *} \\
(0.031)\end{array}$ & $\begin{array}{l}0.045 \\
(0.031)\end{array}$ & $\begin{array}{l}0.057^{* * * *} \\
(0.018)\end{array}$ & $\begin{array}{l}0.125 * * * \\
(0.020)\end{array}$ & $\begin{array}{c}-0.143^{*} \\
(0.081)\end{array}$ & $-73 \%$ \\
\hline
\end{tabular}

Note: The table presents the coefficients of cash flow estimated based on Equation (1). The investment-cash flow sensitivity is estimated separately for each sub-sample. The firms are categorised into low (high) each year based on whether the firm is below (above) the median of the WW Index (Whited, 2006), KZ Index (Kaplan and Zingales, 1997), SA Index (Hadlock and Pierce, 2010), size, firm-age, tangibility (PPE), debt and cash holdings. The other sub-samples are based on whether the firm pays a dividend (Div), reports R\&D, and is classified as being in the industrials sector (IND) based on Industry Classification Benchmark (ICB). The sample consists of listed non-utility and non-financial firms in the UK drawn from Datastream over the period 1992-2016. All variables used are defined in Table 1 and are winsorised at the lower and upper one percentiles. $* * *, * *, *$ indicate significance at the one, five, and ten percent levels, respectively. 


\section{Appendix A Alternative models and estimations of the changes in investment- cash flow sensitivity}

\begin{tabular}{|c|c|c|c|c|c|c|c|c|}
\hline \multirow[b]{2}{*}{ Variables } & \multicolumn{4}{|c|}{$\mathrm{FE}$} & \multicolumn{4}{|c|}{ GMM5 } \\
\hline & (1) & $(2)$ & $(3)$ & $(4)$ & $(5)$ & (6) & $(7)$ & $(8)$ \\
\hline$C F$ & $\begin{array}{l}0.173^{* * *} \\
(0.009)\end{array}$ & $\begin{array}{l}0.262^{* * *} \\
(0.035)\end{array}$ & & & $\begin{array}{l}0.146^{* * * *} \\
(0.022)\end{array}$ & $\begin{array}{l}0.293^{* * *} \\
(0.045)\end{array}$ & & \\
\hline$C F \times p 5$ & & $\begin{array}{l}-0.166^{* * *} \\
(0.037)\end{array}$ & & & & $\begin{array}{l}-0.183^{* * *} \\
(0.046)\end{array}$ & & \\
\hline$C F^{\text {Cycle }}$ & & & $\begin{array}{l}0.127^{* * *} \\
(0.016)\end{array}$ & $\begin{array}{l}0.249 * * * \\
(0.059)\end{array}$ & & & $\begin{array}{l}0.104^{* * *} \\
(0.024)\end{array}$ & $\begin{array}{l}0.270^{* * *} \\
(0.059)\end{array}$ \\
\hline$C F^{\text {Trend }}$ & & & $\begin{array}{l}0.168^{* * *} \\
(0.009)\end{array}$ & $\begin{array}{l}0.253^{* * *} \\
(0.046)\end{array}$ & & & $\begin{array}{l}0.139 * * * \\
(0.021)\end{array}$ & $\begin{array}{l}0.268^{* * *} \\
(0.043)\end{array}$ \\
\hline$C F^{C y c l e} \times p 5$ & & & & $\begin{array}{l}-0.159^{* *} \\
(0.062)\end{array}$ & & & & $\begin{array}{l}-0.173^{* * *} \\
(0.062)\end{array}$ \\
\hline$C F^{\text {Trend }} \times p 5$ & & & & $\begin{array}{l}-0.161^{* * *} \\
(0.048)\end{array}$ & & & & $\begin{array}{l}-0.167^{* * *} \\
(0.045)\end{array}$ \\
\hline$Q$ & $\begin{array}{l}0.004^{* * *} \\
(0.001)\end{array}$ & $\begin{array}{l}0.003 \\
(0.002)\end{array}$ & $\begin{array}{l}0.004^{* * *} \\
(0.001)\end{array}$ & $\begin{array}{l}0.004 \\
(0.003)\end{array}$ & $\begin{array}{l}0.011^{* *} \\
(0.004)\end{array}$ & $\begin{array}{l}-0.002 \\
(0.002)\end{array}$ & $\begin{array}{l}0.012^{* * *} \\
(0.004)\end{array}$ & $\begin{array}{l}0.001 \\
(0.002)\end{array}$ \\
\hline$Q \times p 5$ & & $\begin{array}{l}-0.001 \\
(0.002)\end{array}$ & & $\begin{array}{l}-0.001 \\
(0.003)\end{array}$ & & $\begin{array}{l}0.001 \\
(0.002)\end{array}$ & & $\begin{array}{l}-0.001 \\
(0.002)\end{array}$ \\
\hline$p 5$ & & $\begin{array}{l}-0.004 \\
(0.004)\end{array}$ & & $\begin{array}{l}-0.005 \\
(0.006)\end{array}$ & & $\begin{array}{l}-0.006 \\
(0.006)\end{array}$ & & $\begin{array}{l}-0.005 \\
(0.006)\end{array}$ \\
\hline Constant & $\begin{array}{l}0.029 * * * \\
(0.001)\end{array}$ & $\begin{array}{l}0.033^{* * *} \\
(0.003) \\
\end{array}$ & $\begin{array}{l}0.029^{* * *} \\
(0.001)\end{array}$ & $\begin{array}{l}0.033^{* * *} \\
(0.005) \\
\end{array}$ & $\begin{array}{l}0.021^{* * *} \\
(0.006)\end{array}$ & $\begin{array}{l}0.038^{* * *} \\
(0.005) \\
\end{array}$ & $\begin{array}{l}0.020^{* * *} \\
(0.006) \\
\end{array}$ & $\begin{array}{l}0.036^{* * *} \\
(0.006) \\
\end{array}$ \\
\hline Sample & All & $\mathrm{p} 1 \& \mathrm{p} 5$ & All & $\mathrm{p} 1 \& \mathrm{p} 5$ & All & $\mathrm{p} 1 \& \mathrm{p} 5$ & All & $\mathrm{p} 1 \& \mathrm{p} 5$ \\
\hline Year FE & No & No & No & No & No & No & No & No \\
\hline & 8,072 & 3,206 & 8,072 & 3,206 & 8,072 & 3,206 & 8,072 & 3,206 \\
\hline$R^{2}$ & 0.112 & 0.135 & 0.107 & 0.132 & & & & \\
\hline rho & & & & & 0.118 & 0.133 & 0.115 & 0.132 \\
\hline $\begin{array}{l}\text { Jstat } \\
\text { Jval }\end{array}$ & & & & & $\begin{array}{l}32.44 \\
0.000\end{array}$ & $\begin{array}{l}37.83 \\
0.009\end{array}$ & $\begin{array}{l}32.11 \\
0.000\end{array}$ & $\begin{array}{l}33.81 \\
0.027\end{array}$ \\
\hline
\end{tabular}


Online Appendices

Not For Publication 
Appendix A.1 Sample screening

\begin{tabular}{lrr}
\hline Description & \multicolumn{2}{c}{ Observations } \\
\hline All firms in Datastream (1992-2016) & 0 & 45,575 \\
Less: Duplicates & 12,250 & \\
Less: $\quad$ Financial \& Utility Sectors & 30,727 & \\
Less: Missing key variables & 499 & \\
Less: $\quad$ Large/abnormal changes in assets or sales & 2,099 & 43,476 \\
Less: $\quad$ Firms with less than 5 observations & 8,562 \\
\hline Final sample & 657 \\
\hline Firms & & \\
\hline Note: The table presents the filters or screens used. The sample consists of listed non-utility and non-financial firms in
\end{tabular}

the UK drawn from Datastream over the period 1992-2016. 




